\title{
PENGEMBANGAN SUMBER DAYA MANUSIA HOTEL GRAND ROYAL PANGHEGAR BANDUNG
}

\author{
Anti Riyanti ${ }^{1}$ \\ STIEPAR YAPARI, Bandung \\ anti.ryantik@gmail.com \\ Emron Edison 2 \\ STIEPAR YAPARI, Bandung \\ emron.bdg@gmail.com
}

\begin{abstract}
ABSTRAK
Penelitian ini dilakukan di Hotel Grand Royal Panghegar, Bandung. Tujuan penelitian untuk menganalisis Pengembangan Sumber Daya Manusia (SDM) dalam proses menuju hotel bintang 5. Teknik pengumpulan data melalui observasi partisipasi, wawancara mendalam, dan studi dokumentasi. Hasil penelitian menunjukkan bahwa Hotel Grand Royal Panghegar Bandung telah menyusun Rencana Bisnis (business plan) 2010-2015 salah satu tujuannya adalah menaikkan peringkat bintang. Namun dalam implementasinya, pada saat penilaian di 2015 Hotel Grand Royal Panghegar Bandung tidak berhasil meraih predikat bintang 5 tersebut.

Dari hasil penelitian dan pembahasan yang mendalam menunjukkan bahwa, proses pengembangan sumber daya manusia yang dilakukan belum optimal, dimana strategi pengembangan sumber daya manusia hanya sebatas on job training dan penilaian kinerja dilakukan hanya pada saat masa kontrak kerja karyawan akan berakhir. Karyawan yang memiliki sertifikasi kompetensi masih dibawah $50 \%$. Pengembangan sumber daya mansusia melalui career planning belum terkonsep dengan baik. Kebijakan dan peraturan mengenai pemegang jabatan lebih memprioritaskan kepada pengalaman bekerja. Supervisor melakukan coaching terhadap karyawan melalui diskusi tentang aktivitas keseharian karyawan, namun tidak ada konsep umpan balik (feedback), sehingga karyawan tidak mengetahui kelemahan-kelemahan yang seharusnya perlu diperbaiki. Dari sisi pengembangan sumber daya manusia yang ada ini menunjukkan bahwa penyusunan rencana strategi belum dianalisis dan disusun dengan strategi yang matang.
\end{abstract}

Kata kunci: Pengembangan Sumber Daya Manusia, Pelatihan, Hotel 


\title{
HUMAN RESOURCES DEVELOPMENT IN PANGHEGAR HOTEL BANDUNG
}

\begin{abstract}
This research is done in The Hotel Grand Royal Panghegar Bandung. Research purposes to analyze the development of human resources in the process leading five-star hotel. Data collection techniques through participatory observation, interview and documentation study. Research results show that The Hotel Grand Royal Panghegar Bandung has a business plan in 2010 - 2015, one goal is to raise star rating. But in its implementation at the time did not vote in 2015 The Hotel Grand Royal Panghegar Bandung was awarded the five-star.

The results of research and in-depth discussion shows that the process of development of human resources which do not optimal. Where the human resource development strategy is only limited on the job training and performance assessment is done only at the time of the work contract employees will expire. Employees who have compentence certification is still below 50\%. Human resource development through career planning is not well-thought. Policies and regulations regarding the incumbent higher priority on work experience. Supervisor coaching to employees through a discussion about the daily activities of employees, but there is no concept of feedback, so employees do not know the weaknessesthat should be improved. In terms of human resource development which exist shows that the preparation of the strategic plan have not been analyzed and compiled with a mature strategy.
\end{abstract}

Keywords: Human Resource Development, Training, Hotel.

\section{PENDAHULUAN}

Pariwisata merupakan industri strategis yang diatur dalam UndangUndang No. 10 Tahun 2009 tentang Kepariwisataan, Peraturan Pemerintah No. 50 Tahun 2011 tentang Rencana Induk Pembangunan Kepariwisataan Nasional, dan Peraturan Presiden No. 63 Tahun 2014 tentang Pengawasan Dan Pengendalian Kepariwisataan, serta beberapa peraturan pemerintah lainnya. Tujuan dari regulasi ini agar pariwisata di Indonesia menjadi lebih baik, salah satunya melalui pencitraan dan konsep yang terarah. Namun demikian, keberhasilan pengembangan citra pariwisata tidak terlepas dari sarana akomodasi atau hotel sebagai sektor pendukung.

Keberhasilan pembangunan hotel dan pelayanan prima menjadi bagian 
dari nilai-nilai pariwisata itu sendiri. Di mana kepuasan wisatawan yang didapat merupakan akumulasi dari pelayanan sektor-sektor terkait. Oleh karena itu, manajemen hotel harus dikelola secara profesional sehingga dapat memberikan pelayanan terbaik, dan salah satu faktor kompetitif dalam bisnis pelayanan adalah sumber daya manusia (SDM).

Pengelola hotel perlu juga menyiapkan sumber daya manusia yang memiliki kompetensi, dan menurut Sedarmayanti (2009:125) bahwa "kompetensi mencakup berbagai faktor teknis dan non teknis, kepribadian dan tingkah laku, soft skills dan hard skills." Salah satu cara yang dilakukan oleh pengelola hotel untuk menyiapkan karyawan yang berkompetensi dengan pelatihan dan pengembangan sumber daya manusia serta profesionalisme, meningkatkan kualitas pengelolaan, kemampuan dan keterampilan serta pelayanan di bidang usaha akomodasi, sehingga mampu menjadi karyawan yang terampil dan unggul.

Untuk mengembangkan sumber daya manusia hotel yang unggul dan berkualitas, maka diperlukan langkah-langkah strategis, diantaranya melalui peningkatan kompetensi (pengetahuan, keterampilan dan perilaku), sebagaimana diungkapkan Noe, et.al (2009:8), - the acquisition of knowledge, skills and behaviors that improve an employee's ability to meet changes in job requirements and in customer demands. II Dan agar kompetensi tersebut dapat diakui secara nasional serta global maka perlu standarisasi dan sertifikasi.

Pengembangan sumber daya manusia tidak dapat dilepaskan dengan standarisasi hotel karena untuk menentukan status bintang perhotelan atau standar hotel mencakup tiga aspek yaitu produk, pelayanan dan pengelolaan. Di dalam aspek pengelolaan untuk menjamin terselenggaranya pemberian pelayanan satu indikatornya adalah sumber daya manusia.

Bagi hotel, kompetensi adalah penting, terutama untuk hotel-hotel berbintang, dimana kompetensi itu sendiri merupakan bagian dari konsep pengembangan sumber daya manusia. Pengembangan sumber daya manusia yang baik tentunya melalui langkah-langkah strategis yang dimuat dalam rencana bisnis (business plan). Sebagian besar hotel telah menyusun rencana bisnis, diantaranya adalah Hotel Grand Royal Panghegar Bandung.

Rencana bisnis Hotel Grand Royal Panghegar Bandung 2010-2015: 1) Misi yaitu memberikan nilai tambah kepada shareholder, employees dan community, dengan mengembangkan hubungan yang selaras dengan pemasok (supplier) dan pembelian barang dengan harga terjangkau namun tetap memperhatikan kualitas. Karyawan diperlakukan layaknya pelanggan; 2) Membuat produk Meeting Incentive Conference Exhibition (MICE) bertaraf internasional yang memudahkan jalannya menuju kelas bintang 5 dan siap bersaing dengan para kompetitor; 3) Mengembangkan customer relationship management untuk menetapkan langkah awal strategi bisnis terhadap sumber daya yang diperlukan, baik itu sumber daya manusia dan sumber daya lainnya; 4) Mengelola Gugus Kendali Mutu (GKM) secara intensif menjadi suatu cara meningkatkan kreativitas karyawan untuk berkembang; 5) Menerapkan total customer service secara konsisten dengan mempersiapkan karyawan yang lebih berkualitas dan memberikan kepuasan konsumen, dan; 6) Meningkatkan 
kemampuan manajer untuk melakukan benchmarking.

Sesuai dengan rencana bisnis, tahun 2015 Hotel Grand Royal Panghegar Bandung memasuki masa transisi klasifikasi dari bintang 4 menuju bintang 5 . Namun ada tiga aspek yang menjadi penilaian yang harus dipenuhi oleh hotel bintang dan non bintang seperti diatur dalam Peraturan Menteri Pariwisata Ekonomi Kreatif No. 6 Tahun 2014, yaitu: 1) Aspek produk, meliputi fasilitas, prasarana, sarana, dan utilitas. 2) Aspek pelayanan, meliputi memberikan pelayanan fasilitas hotel kepada tamu, pelayanan keamanan dan kesehatan. 3) Aspek pengelolaan, meliputi organisasi, manajemen dan sumber daya manusia.

Berdasarkan penilaian dari Lembaga Sertifikasi Usaha (LSU) Pariwisata, Hotel Grand Royal Panghegar Bandung belum memenuhi kriteria untuk hotel bintang 5, karena masih terdapat kesenjangan (gap). Kesenjangan tersebut diantaranya: 1) Aspek produk: hotel bintang 5 harus mencapai skor minimal 935, dan skor minimal tersebut belum terpenuhi; 2) Aspek pelayanan: karyawan belum siap dalam masa peralihan hotel bintang 4 menjadi hotel bintang 5 ditunjukkan dengan hasil pekerjaannya yang belum optimal, yang mana terlihat dari guest comment tentang pelayanan hotel, kesiapan karyawan hanya dari aspek pelayanan tidak cukup, karena itu perlu ditinjau dari aspek lainnya; 3) Aspek pengelolaan: Informasi yang diperoleh dari Lembaga Sertifikasi Profesi (LSP) sebagai lembaga yang diberi kewenangan untuk mensertifikasi kompetensi pekerja kepariwisataan terbukti banyak pelatihan yang belum diselenggarakan, seperti: Basic of authentic hospitality, The balanced approach to managing (employee, guest and owner), Managing the works of others (performance, behavior, motivation, opportunity), How to conduct an effective daily communication, Managing the business (occupancy, schedule, accounting). Kemudian untuk hotel bintang 5 harus memiliki minimum 50\% karyawan bersertifikat kompetensi dari jumlah yang ada, dan ini belum terpenuhi.

Melihat permasalahan yang ada, maka penelitian ini lebih difokuskan pada pengembangan sumber daya manusia Hotel Grand Royal Panghegar Bandung. Penelitian ini bertujuan untuk menganalisis sejauhmana pengembangan sumber daya manusia yang telah dilakukan untuk menuju hotel bintang 5. Sedangkan manfaat dari penelitian ini diharapkan dapat dijadikan bahan masukan dan pertimbangan bagi stakeholders untuk mempersiapkan sumber daya manusia yang kompeten dalam menunjang pariwisata yang lebih baik.

Berdasarkan pendapat Sedarmayanti (2009:13),\|manajemen sumber daya manusia adalah kebijakan dan praktik menentukan aspek manusia atau sumber daya manusia dalam posisi manajemen, termasuk merekrut, menyaring, melatih, memberi penghargaan dan penilaian". Dalam pemahaman ini bahwa manajemen sumber daya manusia sebagai suatu kebijakan dalam pengelolaan sumber daya utama pada organisasi melalui aktivitas-aktivitas yang mendukung pencapaian tujuan organisasi dan individu anggota organisasi. Manajemen sumber daya manusia pada hakekatnya penerapan manajemen khususnya untuk mengelola sumber daya manusia. Manajemen sumber daya manusia sebagai suatu strategi dalam menerapkan fungsi-fungsi manajemen yaitu planning, organizing, leading dan controlling dalam setiap aktivitas organisasi. 
Sumber daya manusia yang dimaksud dalam penelitian ini adalah sumber daya manusia hotel yaitu - seseorang atau sekelompok orang yang terlibat dalam kegiatan operasional sebuah hotel yang berperan dalam usaha menghasilkan dan menciptakan produk /jasa untuk pemenuhan kebutuhan konsumen/tamu.ll (RPJMN 2010-2014 Bidang Kebudayaan, Pariwisata, Pemuda dan Olah Raga). Sumber daya manusia dapat memberikan kontribusi yang maksimal terhadap keberhasilan organisasi.

Dalam mengelola sumber daya manusia pada saat ini tidak semudah yang dibayangkan. Manajer atau pemimpin dihadapkan dengan banyak tantangan. Menurut Gomes -Mejia, et.al dalam Kaswan (2010:7), tantangan-tantangan itu jika dikelola dengan efektif bisa menjadi opportunity (peluang), dan jika tidak, bisa menjadi threat / ancaman. Untuk itu sumber daya manusia yang ada perlu dikembangkan, - beberapa fungsi utama dari pengembangan sumber daya manusia adalah 1) Pelatihan dan pengembangan, 2) Pengembangan organisasi, 3) Pengembangan karierll (Kaswan, 2013:2). Bahkan, "Pelatihan dan pengembangan merupakan usaha mengurangi atau menghilangkan terjadinya kesenjangan antara kemampuan karyawan dengan yang dikehendaki organisasill (Sedarmayanti, 2009:163).

Pelatihan merupakan proses meningkatkan pengetahuan dan keterampilan karyawan, sedangkan pengembangan adalah upaya memberi kemampuan kepada karyawan yang akan diperlukan organisasi di masa yang akan datang (Kaswan, 2013:2-3). Senada dengan itu, menurut Noe (2002), pengembangan merupakan kesempatan belajar untuk membantu individu/pegawai dapat berkembang dalam jangka panjang (Sudarmanto, 2009:229). Dengan kata lain, —tujuan pelatihan dan pengembangan antara lain meningkatkan produktivitas kerja, kualitas kerja, ketetapan perencanaan sumber daya manusia, menghindarkan keusangan, dan meningkatkan perkembangan pribadi pegawaill (Mangkunegara, 2009:52). Dengan demikian, pelatihan yang baik harus berfokus pada pengembangan sumber daya manusia ke depan.

Pada dasarnya setiap kegiatan yang terarah tentu memuat hasil yang ingin dicapai dalam melaksanakan kegiatan tersebut. Demikian pula dengan pelatihan dan pengembangan. Tujuan pelatihan dan pengembangan sumber daya mansusia harus dapat memenuhi yang diinginkan perusahaan serta memiliki peranan yang besar dalam menentukan efektifitas dan efisiensi organisasi / perusahaan.

Pelatihan ini bertujuan untuk menyiapkan tenaga-tenaga terlatih yang memiliki keterampilan teknis operasional perhotelan. Kegiatan pelatihan ini dapat ditingkatkan baik kuantitas maupun kualitasnya, sehingga dapat mencetak sumber daya manusia industri pariwisata yang handal dan profesional sesuai dengan tuntutan kebutuhan, yang pada gilirannya akan memberikan kontribusi positif terhadap meningkatnya kunjungan wisatawan nusantara dan mancanegara.

Pendekatan untuk pengembangan karyawan atau sumber daya manusia mengacu pada empat kategori yaitu -Formal education, assessment, job experiences, and interpersonal relationships" (Noe, et.al. 2009:249). Keempat elemen tersebut dapat saling melengkapi antara satu dengan lainnya seperti tampak pada gambar berikut ini: 


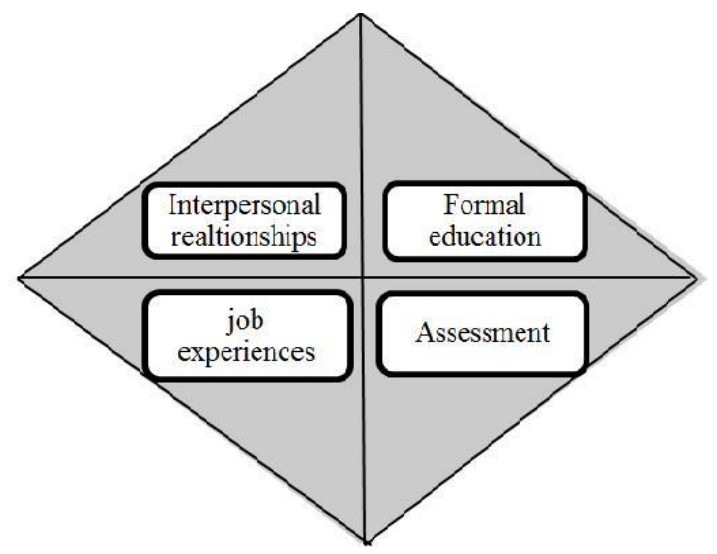

Gambar 1

\section{Empat Pendekatan Pengembangan Karyawan}

Sumber: Fundamentals of Human Resource Management, 2009.

\section{METODE PENELITIAN}

Dalam penelitian ini dibuat desain penelitian yang digunakan sebagai dasar atau patokan dalam melakukan penelitian agar pelaksanaannya dapat berjalan secara terstruktur, dan lancar. Pendekatan metode kualitatif di dalam penelitian ini sebagai upaya untuk mendeskripsikan dan memberi makna yang lebih mendalam dalam menganalisis sebuah penelitian. Desain penelitian dibuat sebagai berikut:

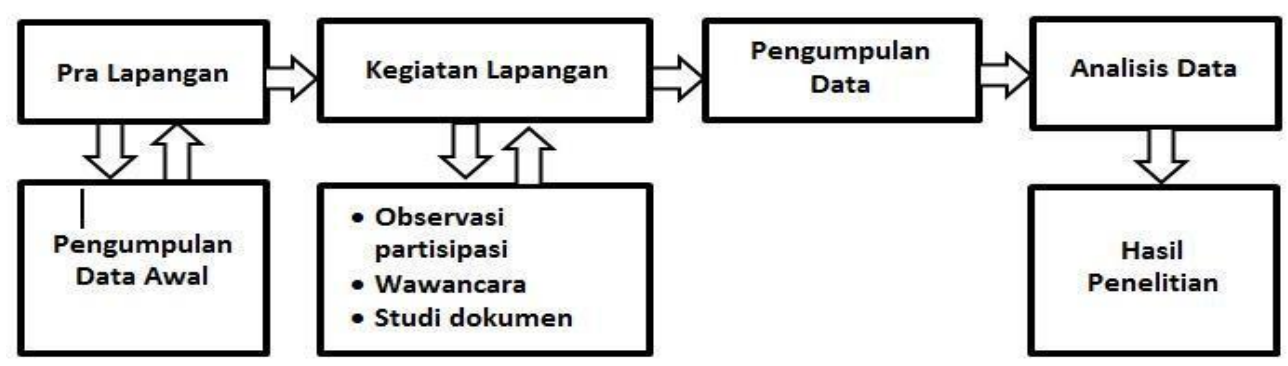

\section{Gambar 2}

\section{Desain Penelitian}

Dijelaskan bahwa tahapan penelitian terdiri dari:

1. Tahap pra-lapangan

Pada tahap ini dilakukan studi pendahuluan (studi literature dan observasi mengenai sumber daya manusia hotel bintang lima dan pengembangannya) untuk melihat kemungkinan dapat melakukan penelitian. Dari hasil observasi, wawancara dan mempelajari literature mengenai manajemen sumber daya manusia hotel, kemudian mendeskripsikan dan mengkaji bagaimana pengembangan sumber daya manusia di hotel tempat penelitian yang dipersiapkan sebagai satu proses untuk menuju hotel bintang lima 
2. Tahap pelaksanaan penelitian

Tahap pelaksanaan penelitian ini merupakan tahap kegiatan lapangan. Kegiatan lapangan ini direncanakan berlangsung kurang lebih 12 bulan. Tahap ini merupakan penelitian yang sesungguhnya, karena terjadi pengumpulan, sekaligus menyeleksi data dan informasi yang dibutuhkan sesuai dengan batasan rumusan masalah dan tujuan serta fokus penelitian, sehingga sampai pada pendeskripsian data yang diperoleh.

3. Tahap pasca-lapangan

Pada tahap ini, akan mengkaji dan mendeskripsikan bagaimana kompetensi sumber daya manusia hotel. Tahap ini juga mengkaji bagaimana tuntutan sumber daya manusia pada hotel bintang lima sehingga ditemukan gap dalam pelaksanaan pengembangan sumber daya manusia di hotel, serta upaya yang ditempuh oleh manajemen dalam meningkatkan kapasitas sumber daya manusia menghadapi persaingan bisnis di industri perhotelan.

Dalam penelitian kualitatif tidak menggunakan istilah populasi, tetapi Spradley (1980) menamakan objek penelitian sebagai "social situation" atau situasi sosial yang terdiri dari tiga elemen yaitu: tempat (place), pelaku (actor) dan aktivitas (activity) (Sugiyono, 2010:215). Penentuan sampel dalam penelitian ini menggunakan purposive sampling yaitu metode penetapan sampel dengan pertimbangan tertentu. Pertimbangan tertentu ini adalah menentukan orang yang dianggap paling tahu dan dapat memberikan data lebih lengkap tentang hotel

dalam mengembangkan sumber daya manusianya, sehingga memudahkan untuk menjelajahi objek/situasi sosial yang diteliti.

Di dalam penelitian ini, peneliti sebagai human instrument ikut berpartisipasi di lapangan, mencatat apa yang terjadi, melakukan analisis reflektif terhadap berbagai dokumen yang ditemukan di lapangan, dan membuat laporan penelitian secara mendetail. Untuk memperoleh data yang akurat, maka penulis bertindak sebagai instrumen utama (key instrument) dengan cara langsung ke lapangan dan menyatu dengan sumber data. Adapun penelitian ini mengacu pada data primer dan sekunder. Data primer diperoleh secara langsung dari objek penelitian yaitu di Hotel Grand Royal Panghegar Bandung melalui wawancara, observasi dan dokumentasi. Data sekunder diperoleh dari sumber-sumber lain yang menunjang penelitian ini, seperti laporan operasional hotel, data dari LSU dan LSP Daerah Jawa Barat, kebijakan dan peraturan tertulis. Sedangkan sumbersumber yang dijadikan informan kunci (key informan) dalam penelitian ini adalah sebagai berikut:

Tabel 1

Sumber Data/Informan Kunci

\begin{tabular}{|c|l|l|}
\hline No & $\begin{array}{c}\text { Sumber Data/Informan } \\
\text { Kunci }\end{array}$ & \multicolumn{1}{c|}{ Informasi Yang Didapat } \\
\hline 1 & LSU Karsa Bhakti Persada & Pengelolaan organisasi dan manajemen hotel. \\
\hline 2 & LSP Daerah Jawa Barat & Pengelolaan SDM hotel dan sertifikasi \\
\hline
\end{tabular}




\begin{tabular}{|c|c|c|}
\hline & (Lembaga Enhai Mandiri) & kompetensi karyawan hotel. \\
\hline 3 & General Manager & $\begin{array}{l}\text { Peraturan perusahaan, program karyawan dan } \\
\text { pelaksanaan sertifikasi kompetensi karyawan. }\end{array}$ \\
\hline 4 & $\begin{array}{l}\text { HR Manager Hotel Grand } \\
\text { Royal Panghegar }\end{array}$ & $\begin{array}{l}\text { Program pendidikan yang dirancang, penilaian } \\
\text { kinerja, pengalaman kerja dan hubungan } \\
\text { personal dengan karyawan. }\end{array}$ \\
\hline 5 & $\begin{array}{l}F \& B \text { Manager Hotel } \\
\text { Grand } \\
\text { Royal Panghegar }\end{array}$ & $\begin{array}{l}\text { Informasi tentang umpan balik kepada para } \\
\text { karyawan tentang perilaku, gaya komunikasi, } \\
\text { dan keterampilan. Pengembangan dan pelatihan } \\
\text { karyawan. Hubungan personal dengan para } \\
\text { karyawan. }\end{array}$ \\
\hline 6 & $\begin{array}{l}\text { FO Manager Hotel Grand } \\
\text { Royal Panghegar }\end{array}$ & $\begin{array}{l}\text { Informasi tentang umpan balik kepada para } \\
\text { karyawan tentang perilaku, gaya komunikasi, } \\
\text { atau berbagai keterampilan. Pengembangan dan } \\
\text { pelatihan karyawan. Hubungan personal dengan } \\
\text { para karyawan. }\end{array}$ \\
\hline 7 & $\begin{array}{l}\text { Sales Hotel Grand Royal } \\
\text { Panghegar }\end{array}$ & $\begin{array}{l}\text { Informasi tentang umpan balik kepada para } \\
\text { karyawan tentang perilaku, gaya komunikasi, } \\
\text { atau berbagai keterampilan. Pengembangan dan } \\
\text { pelatihan karyawan. Hubungan personal dengan } \\
\text { para karyawan. }\end{array}$ \\
\hline 8 & $\begin{array}{l}\text { Supervisor masing-masing } \\
\text { divisi Hotel Grand Royal } \\
\text { Panghegar }\end{array}$ & $\begin{array}{l}\text { Peraturan perusahaan hotel, prosedur, } \\
\text { kompetensi karyawan, program hotel yang } \\
\text { ditawarkan, dan hubungan personal. }\end{array}$ \\
\hline
\end{tabular}

Sumber: Data olahan peneliti

Dalam penelitian ini peneliti menggunakan tiga teknik pengumpulan data yaitu sebagai berikut:

1. Observasi partisipasi (participant observation) adalah metode pengumpulan data yang digunakan untuk menghimpun data penelitian melalui pengamatan dan penginderaan di mana peneliti terlibat dalam keseharian informan (Bungin, 2012:118). Pengamatan langsung dilakukan pada Hotel Grand Royal Panghegar Bandung berupa aktivitas kegiatan. Adapun jenis data yang diperoleh dari hasil pengamatan secara langsung adalah berkaitan dengan:

a. Pelaksanaan pengembangan sumber daya manusia yang dilakukan oleh manajemen Hotel Grand Royal Panghegar Bandung.

b. Upaya yang dilakukan oleh manajemen Hotel Grand Royal Panghegar Bandung dalam mengembangkan sumber daya manusia hotel untuk masa peralihan menuju hotel kelas bintang 5 . 


\section{Wawancara (Interview)}

Wawancara yang digunakan dalam penelitian ini adalah wawancara tidak terstruktur, dengan maksud untuk mengumpulkan informasi sebanyakbanyaknya dari narasumber dan mendalam (in-depth investigation), serta untuk memilih dan merumuskan masalah dalam satu studi pendahuluan atau penjajakan, sehingga beberapa faktor yang menjadi pusat untuk masalah utama dalam penelitian dapat tergali. Pedoman wawancara ini yang peneliti gunakan untuk mewawancarai pihak internal hotel, seperti: general manager, hrd manager, $f \& b$ manager, sales manager, supervisor, dan pihak eksternal hotel, seperti: LSU dan LSP Daerah Jawa Barat.

\section{Studi Dokumentasi}

Dengan teknik studi dokumentasi ini, peneliti memperoleh informasi bukan dari orang sebagai narasumber, tetapi dari berbagai sumber tertulis atau dari dokumen yang ada pada informan. Studi dokumentasi bermanfaat melengkapi hasil observasi atau wawancara, sehingga hasil tersebut akan lebih kredibel atau dapat dipercaya dengan dukungan dari dokumen yang terkait dengan fokus penelitian. Dari studi dokumentasi ini dapat diperoleh dokumen-dokumen pendukung, seperti peraturan perundangan, laporan penilaian (appraisal) tahunan, data kepegawaian, kebijakan tertulis dan lain-lain.

Beberapa pertimbangan yang menjadi landasan, memilih pendekatan kualitatif adalah:

1. Fenomena yang kompleks dan abstrak, sehingga membutuhkan pengkajian lebih komprehensif dan mendalam, melalui pendekatan ini diharapkan akan mampu mengungkap dan memberikan informasi yang akurat sehingga sangat membantu proses interpretasi informasi dan data yang diperoleh.

2. Melalui proses ini diharapkan juga muncul proposisi hipotetik baru melalui interpretasi Antara atribut dan propretise yang selanjutnya digunakan untuk membangun kategori dan memberikan eksplanasi terhadap fenomena yang diteliti.

Pada dasarnya, metode-metode pengumpulan data dalam penelitian kualitatif sekaligus juga adalah metode analisis data, dengan kata lain prosedur metodis sekaligus juga strategi analisis data itu sendiri, sehingga proses pengumpulan data juga sekaligus adalah proses analisis data. Dengan demikian, proses pengumpulan data juga adalah proses analisis data, karena itu seelah data dikumpulkan maka sesungguhnya sekaligus peneliti sudah menganalisis data (Bungin, 2011:79).

Maka jelas bahwa analisis data penelitian ini dimulai dari mengumpulkan data, kemudian proses reduksi data dengan cara memilah data yang penting atau tidak, lalu menyajikan data dan yang terakhir menyusun kesimpulan. Setelah itu disajikan dalam bentuk deskriptif. Ukurannya mengacu pada kontribusi data pada upaya menjawab fokus penelitian. Lewat data yang diperoleh informasi yang lebih bermakna dan untuk menentukan makna tersebut diperlukan pengertian mendalam, kreativitas, kepekaan konseptual dan pengalaman. Pendekatan yang 
digunakan yaitu bertindak sebagai seorang yang mengidentifikasi masalah informan dan menguraikan apa yang telah didengar secara nyata tanpa mengurangi atau mempengaruhi opini responden.

\section{HASIL DAN PEMBAHASAN}

Keberhasilan pendayagunaan dan pengembangan sumber daya manusia sangat ditentukan oleh berbagai aspek di dalam organisasi. Tidak ada pola pendayagunaan dan pengembangan sumber daya manusia yang baku dan tepat atau sesuai untuk semua organisasi. Bentuk yang tepat adalah pendayagunaan dan pengembangan sumber daya manusia yang harus diupayakan, berproses dan dapat berubah dari waktu ke waktu atau bersifat dinamis.

Salah satu fungsi dari manajemen sumber daya manusia adalah pengembangan sumber daya manusia. Kualitas organisasi bergantung pada mutu sumber daya manusia organisasi tersebut. Kebutuhan ini semakin kuat dirasakan ketika organisasi menghadapi tantangan-tantangan yang dihadirkan oleh ekonomi yang semakin global, bergerak cepat dan sangat diamis. Agar mampu bersaing dan berkembang dengan pesat, pelatihan dan pengembangan merupakan bagian strategi utama organisasi.

Pengembangan karyawan melalui pelatihan merupakan proses peningkatan kemampuan karyawan yang dilakukan melalui berbagai cara untuk hasil yang lebih baik dalam meningkatkan kompetensi baik bagi individu maupun bagi organisasi. Kemudian pengembangan karir yang kegiatannya dimulai dari karyawan berisikan perbaikan-perbaikan yang dilakukan individu untuk mencapai rencana karirnya. Kompetensi sumber daya manusia yang handal dan profesional serta mutu pendidikan di bidang pariwisata melalui penerapan standarisasi, sertifikasi dan akreditasi. Selain pemenuhan dasar kebutuhan tamu, pengelola hotelpun memiliki target untuk menambah tingkat hunian kamar.

Berdasarkan Peraturan Menteri Pariwisata Ekonomi dan Kreatif Nomor PM 53 /HM/MPEK/2013 tentang Standar Usaha Hotel dijelaskan bahwa - standar adalah suatu hasil yang direncanakan, standar menetap adalah apa dan bagaimana produk secara keseluruhan, yaitu produk yang seharusnya ditawarkan kepada tamu.II Dalam sebuah hotel terdapat beberapa jenis standar sebagai berikut:

1. Prasarana dan ketentuan bagi para pelaksana yang meliputi segala aspek yang berkaitan dengan administrasi para pelaksana, disiplin dan sebagainya.

2. Standar fasilitas, yaitu standar fasilitas yang terdiri dari ukuran dan jenis fasilitas fisik yang semuanya itu harus diterapkan mulai sejak awal hotel yang bersangkutan dibuka termasuk juga standar fasilitas.

3. Standar makanan dan minuman

4. Standar pelayanan

Keterkaitan antara pengembangan sumber daya manusia dengan standarisasi hotel merupakan hal yang tidak dapat dilepaskan karena untuk menentukan status bintang perhotelan atau standar hotel meliputi tiga komponen yaitu produk, pelayanan dan pengelolaan. Di dalam komponen pengelolaan meliputi organisasi, manajemen dan sumber daya manusia, disebutkan untuk 
menjamin terselenggaranya pemberian pelayanan salah satu indikatornya adalah sumber daya manusia. Maka karyawan hotel merupakan sentral utama sebagai pemberian layanan berupa penyediaan akomodasi, restoran dan pelayanan lainnya untuk dapat memberikan pelayanan prima juga memenuhi kebutuhan konsumen hotel.

Terdapat perbedaan dalam pelatihan dan pengembangan, yaitu pelatihan difokuskan kepada keterampilan teknis dan diberikan bagi pegawai yang tidak duduk pada jabatan pengelolaan (non manajerial) sedangkan pengembangan diberikan untuk pegawai pada kedudukan pengelolaan (manajerial) dengan fokus materi lebih bersifat konseptual dan teoritis. Dalam proses pengembangan orang tidak memulai dari sesuatu yang sama sekali baru, namun pengembangan adalah membangun, memperluas, mentransformasi dan beradaptasi dengan pengetahuan, pemahaman dan keterampilan yang telah ada.

Menurut Noe, R. A. dkk (2010: 528) —ada empat pendekatan yang digunakan untuk mengembangkan karyawan dalam suatu organisasi yaitu:

1. Pendidikan formal, meliputi program-program di luar dan di dalam perusahaan yang dirancang khusus bagi para karyawan, seperti kursuskursus singkat yang ditawarkan konsultan, mengirimkan karyawan mengikuti program yang ditawarkan universitas.

2. Penilaian (assessment) meliputi mengumpulkan informasi dan memberikan umpan balik kepada para karyawan tentang perilaku, gaya komunikasi atau berbagai keterampilannya.

3. Pengalaman kerja (job experiences) meliputi hubungan, masalah, tuntutan, tugas atau ciri yang dihadapi para karyawan pada pekerjaannya. Asumsi utama dari menggunakan pengalaman pekerjaan untuk pengembangan karyawan adalah pengembangan paling mungkin terjadi ketika ada ketidakcocokan antara keterampilan karyawan dengan pengalaman di masa lalu serta keterampilan yang dibutuhkan pada pekerjaan.

4. Hubungan-hubungan antar pribadi, para karyawan mengembangkan berbagai keterampilan dan meningkatkan pengetahuan tentang perusahaan dan para pelanggannya dengan berinteraksi bersama anggota yang lebih berpengalaman melalui mentoring, coaching, counseling, diskusi dan sebagainya.

Hasil penelitian menunjukkan bahwa, khususnya dalam pengembangan sumber daya manusia implementasinya kurang berjalan baik, di mana pengembangan sumber daya manusia dilakukan melalui pendidikan dan pelatihan internal dengan cara mengirim karyawan untuk mengikuti pendidikan ke lembaga group yang dimiliki hotel. Pelatihan internal yang dilakukan cenderung masih bersifat administrasi, kurang fokus pada kompetensi. Dengan adanya tuntutan profesional, sumber daya manusia hotel harus memiliki kompetensi dan tersertifikasi melalui pengembangan dan pelatihan. Bahkan menurut Bangun (2012:201), "seorang manajer yang tidak peduli terhadap kegiatan pelatihan akan menerima resiko yang dapat membahayakan kegiatan operasional perusahaan. Hal ini dapat dilihat bahwa perkembangan teknologi yang semakin melejit dewasa ini dapat mengakibatkan terjadinya perubahan yang semakin dahsyat pada berbagai 
aspek yang dialami suatu perusahaan." Salah satu upaya yang ditempuh adalah menyelenggarakan program pelaksanaan pendidikan dan pelatihan secara bertingkat menurut kualifikasi yang diperlukan untuk memelihara kesinambungan pembinaan kepribadian, sikap, pengetahuan dan kemampuan sesuai dengan tuntutan persyaratan yang diembannya.

Beberapa pelatihan telah dilakukan seperti: Standard Operational Procedure (SOP), tapi karyawan cukup diperkenalkan dan diberikan modul sebagai pedoman untuk bekerja, sehingga pemahaman terhadap SOP itu sendiri masih lemah. Begitu juga untuk pelatihan bahasa, hasil penelitian menunjukkan bahwa kompetensi karyawan dalam berbahasa asing masih rendah, di mana pelatihan hanya dilakukan satu bulan sekali, ini dirasakan belum cukup. "oleh karena tidak pernah ada evaluasi setelah pelatihan, sedangkan pelatihan akan efektif bila ada umpan balik atas apa yang mereka sedang lakukan" (Rivai, Basri, Sagala, Murni, 2008). Dan "pelatihan akan efektif bila karyawan termotivasi untuk belajar dan menyadari perlunya meningkatkan keterampilan demi terlaksananya pekerjaan dan terpenuhinya kepuasan lain" (Rivai, Basri, Sagala, Murni, 2008).

Pelatihan Sistem Operational PowerPro (SEO) dimana pelatihan ini diselenggarakan untuk level supervisor ke atas bagian room division. Sistem komunikasi (SEO) ini merupakan jaringan antar departemen atau hubungan dengan tamu. Hasil penelitian menunjukkan kemampuan karyawan dalam mengaplikasikan sistem ini masih kurang. Sedangkan pelatihan handling complaints hanya diperuntukkan untuk karyawan bagian frontliner, sehingga kemampuan karyawan dalam mengatasi keluhan tamu masih kurang. "sebenarnya faktor yang perlu diperhatikan dalam pengembangan diantaranya partisipasi aktif dan seleksi peserta" (Mangkunegara, 2009:53).

Manajemen sudah melakukan kerja sama dengan LSP untuk melaksanakan sertifikasi kompetensi bagi karyawan. Namun, program tersebut belum dilakukan secara merata, karena operasional yang padat dan kurang terencana dengan baik, sehingga sertifikasi masih dibawah $50 \%$ dari 325 total karyawan yang ada. Standar kompetensi merupakan pernyataan keterampilan, pengetahuan dan sikap wajib diterapkan dalam rangka memenuhi persyaratan standar industri. Standar kompetensi menyediakan sebuah lingkungan kerja yang sesuai dengan kebutuhan semua pemegang saham yaitu industri, pemerintah, para penyelenggara pelatihan, dan para pelatih tanpa mempertimbangkan lokasi dan proporsi, agar relevan dan penuh arti sangat penting untuk menyelenggarakan suatu pelatihan dan penilaian yang sesuai standar dengan suatu cara yang akan memenuhi kebutuhan peserta dan sektor industri tertentu. Dengan cara ini kebutuhan pelatihan yang sebenarnya akan tercapai.

Berdasarkan Lembaga Sertifikasi Profesi (LSP)-Badan Nasional Standarisasi Profesi (BNSP) bidang akomodasi tahun 2006, kompetensi sumber daya manusia bidang akomodasi terbagi dalam, "kompetensi umum, pelayanan makanan dan minuman, kantor depan, tata graha, keamanan, pelayanan pelanggan dan penjualan, kesehatan kebersihan dan keselamatan, administrasi umum, administrasi keuangan, teknologi, pelatihan, kepemimpinan, kecakapan dalam 
berbahasa Inggris mendengar dan berbicara, pengolahan dan penghidangan masakan komersial, jasa boga komersial."

Disisi lain, kurangnya dukungan manajemen terhadap karyawan untuk melanjutkan pendidikan formal di perguruan tinggi meskipun atas biaya sendiri. Data menunjukkan, sebanyak $40 \%$ karyawan masih berpendidikan diploma satu dan SMK, sedangkan sarjana (S1) 16\%, kondisi ini dapat mempengaruhi kompetensi manajerial. Meskipun "pada kenyataannya kebijakan pengembangan sumber daya manusia harus memperhitungkan aspirasi dan kebutuhan individu" (Sedarmayanti, 2009:167), bagaimanapun juga manajemen harus peka terhadap kebutuhan tenaga kerja yang berpendidikan tinggi dan professional untuk tingkat manajerial.

Dari hubungan personal fakta di lapangan menunjukkan bahwa, coaching yang dilakukan oleh supervisor terhadap karyawan melalui diskusi tentang aktivitas keseharian karyawan, supervisor mengidentifikasi kelemahan dan kelebihan karyawan dan melaporkan dalam bentuk hasil penilaian kepada manajer untuk dievaluasi setiap satu tahun sekali dan tidak terjadwal. Namun kegiatan coaching tidak dilakukan dengan terbuka dan tidak dikomunikasikan kepada karyawan yang bersangkutan. Karyawan hanya menerima hasil penilaian dari atasan. Sedangkan mentoring dan counseling tidak dilakukan. Padahal dengan adanya mentoring menurut Armstrong, bertujuan untuk membantu pengembangan diri dan kemajuan karir karyawan (Sudarmanto, 2009:240).

Hubungan antar pribadi ini merupakan upaya pemberdayaan karyawan dari sisi membangun kepercayaan dan pengembangan pengetahuan serta keterampilan untuk meningkatkan kompetensi. Coaching merupakan pembinaan yang dilakukan oleh manajer atau atasan kepada staf dalam kerangka perbaikan kinerja (Sudarmanto, 2009:237). Sebagaimana supervisor atau penyelia berfungsi sebagai konsultan karyawan, karyawan bekerja sebagai inisiator, yang berusaha untuk memberikan dampak aktivitas pengembangan sumber daya manusia yang akan dilakukan (Rivai dkk., 2008:163). Fungsi penyelia tidak hanya sebagai konsultan karyawan namun berfungsi juga sebagai pengawas sistem pelaksanaan standar operasional prosedur, sistem perekrutan karyawan, sistem penilaian kinerja karyawan dan sistem pendidikan (Bartono dan Ruffino, 2010: 81-84).

Sistem penilaian yang dilakukan oleh manajemen hanya sebatas informal. Penilaian para manajer terhadap karyawan tidak dilakukan secara berkala, sering kali dilakukan pada saat kontrak kerja karyawan hampir berakhir yaitu untuk menentukan kontrak berlanjut atau tidak. Selain itu, penilaian digunakan sebagai keputusan untuk pemberian reward kepada karyawan. Namun sistem pemberian reward ini belum efektif, karena insentif yang diterima oleh semua karyawan adalah sama yang didapatkan dari hasil keuntungan, bukan berdasarkan hasil penilaian kinerja. Padahal, "Penilaian kinerja menolong manajer mengidentifikasi orang-orang yang akan diimbali karena kinerjanya yang memadai atau unggul dan orang-orang yang tidak. Kendatipun demikian, penilaian kinerja dapat mendatangkan hasil yang keliru manakala penilai bias atau standar evaluasi tidak jelas. Masalah proses penilaian kinerja harus dikenali dan diminimalkan oleh penyelia terlatih, orang yang seyogyanya tidak hanya mengetahui masalahnya saja, tetapi juga mempelajari bagaimana menghindari kesalahan penilaian yang 
lazim terjadi" (Simamora, 2004:351). Selain itu, "penilaian ini digunakan beberapa di antaranya untuk menentukan kebutuhan-kebutuhan pelatihan organisasi dan perencanaan sumber daya manusia" (Rivai dkk., 2008:50).

Perencanaan karier (career planning) telah diprogramkan, namun program ini belum berjalan efektif dan terbuka untuk semua lapisan karyawan, padahal menurut Yani (2012:109), —departemen personalia haruslah secara aktif dalam perencanaan karier (career planning) para karyawannya." Dalam perencanaan karir menurut Fayol (1949), penempatan karyawan harus menggunakan prinsip the right man in the right place. Dengan adanya prinsip orang yang tepat di tempat yang tepat (the right man in the right place) akan menopang terhadap kestabilan, kelancaran dan efesiensi kerja.

\section{SIMPULAN}

Pengembangan sumber daya manusia yang dilakukan oleh manajemen Hotel Grand Royal Panghegar Bandung belum dilakukan secara komprehensif dan efektif. Dalam pengembangan ini, manajemen baru memprioritaskan kepada pengalaman kerja, belum pada konsep pengembangan sumber daya manusia secara utuh, menyeluruh dan merata, seperti: perluasan pekerjaan, peralihan karyawan, perputaran pekerjaan, pendidikan, rencana karir, dan pelatihan. Pelatihanpun masih bersifat on job training tidak ada off job training, kurang berbasis kompetensi. Disisi lain coaching yang dilakukan oleh para supervisor hanya sebatas memenuhi unsur program.

Kompetensi sumber daya manusia Hotel Grand Royal Panghegar Bandung yang telah tersertifikasi oleh LSP Pariwisata Daerah Jawa Barat masih dibawah $50 \%$. Untuk menuju hotel bintang 5 perlu memperluas jumlah karyawan yang memiliki sertifikasi kompetensi. Dan, pelatihan-pelatihan perlu dirancang dalam konsep pengembangan sumber daya manusia dalam menghadapi tantangan ke depan, dan layanan terbaik, salah satunya adalah melalui pelatihan-pelatihan berbasis kompetensi dan peningkatan kemampuan manajerial untuk para pengambil keputusan. Untuk itu manajemen perlu merancang program dengan indikator-indikator dan capaian yang jelas dan terukur.

Hubungan personal sebagai upaya pemberdayaan dan pengembangan karyawan di antaranya melalui coaching. Coaching ini dilakukan oleh supervisor melalui diskusi tentang aktivitas keseharian karyawan. Supervisor mengidentifikasi kelemahan dan kelebihan karyawan dan melaporkannya ke manajer untuk penilaian yang akan dievaluasi setiap satu tahun sekali. Namun, hasilnya tidak dikomunikasikan kepada karyawan yang bersangkutan, tidak ada umpan balik (feedback), karyawan langsung menerima penilaian apa adanya. Ini dikarenakan manajemen belum memahami makna dari tujuan coaching itu sendiri. Manajemen perlu mengevaluasi proses selama ini dengan memadukan mentoring, coaching, dan counseling, sehingga karyawan merasa diperhatikan dan memahami kekurangan yang dimilikinya untuk dapat diperbaiki.

Penilaian kinerja karyawan masih bersifat konvensional yakni dilakukan pada saat masa kontrak kerja karyawan akan berakhir. Hasil penilaian ini yang dijadikan manajemen dalam mengambil keputusan untuk memberikan reward 
sebagai bagian dari persiapan masa depan karyawan yang bersangkutan. Sistem reward ini bukan ke arah pengembangan sumber daya manusia, karena tidak berbasis kinerja. Ini dikarenakan manajemen belum memahami manfaat dan efektivitas reward. Oleh karena itu, perlu diperhatikan bahwa dalam sistem reward harus didasarkan pada kinerja dan indikator yang jelas, sebab reward yang efektif harus dapat memacu persaingan yang positif dan perbaikan kinerja.

Begitu pula dengan sistem rencana karir (career planning), tidak ada konsep yang jelas. Disisi lain, kurangnya dukungan manajemen terhadap karyawan untuk melanjutkan pendidikan tinggi secara mandiri, padahal dengan makin baiknya pendidikan, makin baik pula kompetensi seseorang yang pada akhirnya dapat meningkatkan kinerja.

\section{DAFTAR PUSTAKA}

Bartono \& Ruffino (2010), Hotel Supervision dan Uji Kompetensi untuk Pendidikan Pariwisata. Yogyakarta: Andi.

Bungin, B. (2012), Penelitian Kualitatif, Jakarta: Kencana.

Kaswan (2010), Manajemen Sumber Daya Manusia, Bandung: Putra Praktisi

Kaswan (2013), Pelatihan dan Pengembangan SDM. Bandung: Alfabeta.

Kramer, D.K. (2010), Management Theoretician Henri Fayol's 14 Principles Discussed. January 21, 2010.

Lembaga Sertifikasi Profesi (LSP). (2006). Badan Nasional Standarisasi Profesi (BNSP) Bidang Akomodasi. Struktur Kompetensi Sumber Daya Manusia Pariwisata Bidang Akomodasi.

Mangkunegara, A.P. (2009), Perencanaan dan Pengembangan Sumber Daya Manusia, Bandung: Refika Aditama.

Noe, R. A. et. al. (2009), Fundamentals of Human Resource Management (Int Ed). New York: McGraw Hill.

Noe, R. A et al. (2010), Manajemen Sumber Daya Manusia:mencapai keunggulan bersaing (edisi 6 buku 1). Jakarta: Penerbit Salemba Empat

Peraturan Menteri Pariwisata Ekonomi dan Kreatif. (2013). Standar Usaha Hotel. Nomor. PM 53/HM/MPEK/2013. Menteri Pariwisata Ekonomi dan Kreatif.

Rivai V. et al. (2008), Performance Appraisal - Sistem yang Tepat untuk Menilai Kinerja Karyawan dan Meningkatakan Daya Sing Perusahaan. Jakarta: RajaGrafindo Persada.

Salinan Peraturan Menteri Pariwisata Ekonomi dan Kreatif (2014). Nomor 6 Tahun 2014 tentang Perubahan atas PermenParekraf Nomor PM 53/HM/MPEK/2013 tentang Standar Usaha Hotel. Menteri Pariwisata Ekonomi dan Kreatif. 


\section{Tourism Scientific Journal}

Volume 2 Nomor 1 Desember 2016

Sedarmayanti, (2009), Manajemen Sumber Daya Manusia -Reformasi Birokrasi dan Manajemen Pegawai Negeri Sipil. Bandung: Refika Aditama.

Silalahi, U. (2010). Metode Penelitian Sosial. Bandung: Refika Aditama.

Henry S. (2004), Manajemen Sumber Daya Manusia. Edisi ke-3, Yogyakarta: STIE YKPN.

Sudarmanto. (2009), Kinerja dan Pengembangan Kompetensi SDM- Teori, Dimensi Pengukuran dan Implementasi dalam Organisasi. Yogyakarta: Pustaka Pelajar.

Sugiyono. (2010), Metode Penelitian Kuantitatif, Kualitatif, dan R\&D. Bandung: Alfabeta.

Yani, H. M. (2012), Manajemen Sumber Daya Manusia, Jakarta: Mitra Wacana Media.

\section{Online:}

http://bappenas.go.id/files/4213/5228/2124/background-study-2008pembangunan bidang-kebudayaan-2010-2014_20110202135808_ $\quad$ 0.pdf $\quad$ (diakses tanggal 1 November 2017)

https://davidkramer.wordpress.com/2010/01/21/management-thinker-henri-fayol-14principles-discussed/ 